\title{
Between material culture and "living room art": Historicizing the restitution of fascist-looted art
}

\author{
Bianca Gaudenzi and Lisa Niemeyer
}

German Historical Institute in Rome; Wolfson College, Cambridge; Zukunftskolleg, University of Konstanz

Corresponding author: Bianca Gaudenzi, email: bg265@cam.ac.uk

In April 1942, former carpet manufacturer Felix Ganz wrote to his daughter Annemarie with a sketch of their new home. After their business had been forcibly Aryanized and they were evicted from their family home in the spring of 1941, Felix and his wife Erna were coerced into moving to smaller and smaller quarters three times, until their deportation to Theresienstadt in the late summer of 1942. Both would be murdered at Auschwitz the following year. In his letter, Felix illustrated how they had furnished the one-room apartment with what was left of their furniture and artworks. Stripped of most of their cultural belongings including Felix's gramophone and record collection - the couple had attempted to keep the pieces of material culture most significant to them, such as a Persian lamp and a few family portraits. Theirs was not a prominent art collection but, rather, a brilliant exemplification of Wohnzimmerkunst - that "living room art" of more modest artistic quality that fulfilled a central social function for the upper middle-class milieus of the nineteenth and early twentieth centuries, as illustrated by Emily Löffler in this issue. ${ }^{1}$ It was a visual and material marker of their social status, of their level of education, and also of their family as well as individual identities. Besides the evident economic intent of fascist plundering, it was precisely this sense of self and of belonging that the Nazis (and the Fascists) set out to annihilate. $^{2}$

Ever since news of the "discovery" of the Gurlitt trove first broke in 2012, the restitution of cultural property has been on the crest of an apparently unstoppable wave. Besides the well-established provenance research into Jewish-owned cultural property, postcolonial restitution has increasingly become the epicenter of fierce disputes, as in the case of the contested Benin Bronzes or the repatriation of the Cape cross stone to Namibia. The public and scholarly disputes that have ensued reveal just how contested the field of looted art still is and how much art as a unique form of property engages the fantasy and interest of the public and academics alike. As a result, the restoration of material culture has now risen to one of the central facets of post-authoritarian justice, which historians have yet to analyze in more comprehensive terms.

This collection of articles results from one central question that underpins our work as historians dealing with restitution matters: what role does research into fascist-looted art play in the bigger picture? How, if at all, does it enhance our knowledge of twentiethcentury history, and how does it contribute to our understanding of broader historical

\footnotetext{
${ }^{1}$ See Emily Löffler, "Living Room Art" and the Material Culture of Provenance: Retracing Bourgeois Everyday Life and Art Collecting Practices through Restitution Files" in this issue.

${ }^{2}$ The term "fascism" refers to generic fascism and capitalized "Fascism" to Italian Fascism. 
developments? And what is so special about cultural property anyway, as some fellow historians ask who are still critical of such cultural or visual turns? The exponential growth of provenance research has provided us with an ever-expanding array of wellresearched, in-depth studies into the trajectories of single artworks or of specific collections, collectors, or art dealers. These contributions sometimes leave the historical context in the background in favor of an impressive number of details, which are essential for establishing the provenance of an artwork. This is the result of different scholarly and disciplinary traditions, for sure, and yet it is often the works that manage to combine diverse approaches that lead to the most rewarding results. Historicization plays a paramount role here.

As this special issue shows, compelling results can be achieved through a thorough historicization of cultural restitution. From cross-examining pictorial analysis with coeval psychological interpretations to examining the social role of "everyday art" as identity markers, intertwining the study of material culture with the politics of gender, nationbuilding processes, identity politics, or Cold War history opens up an entire new realm of possibilities. Historicizing also means counteracting one of the main pitfalls of mainstream cultural restitution - that is, its class disparity, by moving past causes célèbres and worldrenowned collections to analyze the nitty-gritty of Alltagsobjekte (everyday objects) or of the "living room art" that adorned Jewish and non-Jewish bourgeois homes as an expression of the owners' status and identity. Furthermore, it allows us to see how the meaning of objects changed over time - not only in their political significance, as in the case of the worldrenowned Ghent altarpiece, but also in their materiality. This is once again evidenced by the varied fate of those family objects that upper- or middle-class Jews decided to bring with them from home during the moves forced upon them during their persecution and up to their deportation.

This special issue brings together original historical, art historical, and provenance perspectives on the restitution of fascist-looted art with the intent of providing a muchneeded interdisciplinary historicization of the subject. It thereby offers a comprehensive interpretation of the historical relevance of cultural property in contemporary Europe by exploring the manifold meanings of art as a historical source. All of the articles contextualize the role of art within a broader historical narrative in order to investigate tangible links to current debates originating from a variety of fields, including social and cultural history, the study of material culture as well as gender studies. In doing so, the issue contributes new elements to tackle some of the central questions that underpin the history of the twentieth century and beyond. These include the role of cultural heritage in postwar nation building; the reasons for the persistence of anti-Semitism in post-1945 Europe; the gendered experience of Allied forces in occupied Germany; the emphasis on private property for the reestablishment of the rule of law in Western Europe; the importance of cultural restitution for transitional justice processes; the impact of exile and migration on the reframing of national and individual identities; the political role of art beyond cultural diplomacy at the height of the Cold War; the primarily economic character of the Wiedergutmachung (reparations) process until the late 1960s; and, finally, the notion of the centrality of the Cold War in hampering a fully-fledged Vergangenheitsbewältigung (the "struggle to cope with the past"). ${ }^{3}$ There are other fundamental questions that fall outside of the scope of this issue, though - first and foremost, the impact of neoliberal policies on the "second-wave" restitution campaigns of the 1990s, as argued by Regula Ludi, or the issue of the discursive as well as practical similarities between post-fascist and postcolonial restitution. ${ }^{4}$

\footnotetext{
${ }^{3}$ See Gaudenzi 2021.

${ }^{4}$ Ludi 2018. For an overview, see Gaudenzi and Swenson 2017.
} 
By shifting the focus onto restitution rather than looting, the issue moves past the debate over the "unicity" of Nazi looting in order to examine the still under-researched implications of cultural restitution for the history of post-1945 Western Europe. It is a primarily Central European history, with ramifications in several directions - the Baltic countries, Britain, the Soviet Union, and the United States, in particular - as many transnational paths were followed by human beings and objects alike. Concentrating on a quintessentially transnational phenomenon such as restitution also proves helpful in highlighting how the rhetoric of local, national, and international "imagined communities" were constructed again after $1945 .^{5}$ In this context, the choice of the term "restitution" is motivated by its frequent use in the sources, as no actual reparation nor Wiedergutmachung (the controversial "making good again") - either ideal or material - would ever be conceivable.

This special issue grew out of a selection of papers presented at the international conference "From Refugees to Restitution: The History of Nazi Looted Art in Transnational Perspective" that took place at the University of Cambridge in March 2017. Through a selection of archive-based contributions, the issue delivers an innovative examination of the current research landscape by firmly contextualizing the topic within the broader historical context of Cold War Europe. The necessity of bringing forward a more comprehensive historicization of the subject appears particularly pressing not only by virtue of the topic's public relevance but also especially of its potential to unearth new historical nuances that could significantly enrich our interpretation of contemporary Europe. For this reason, the persistent lack of far-reaching historical interpretations of the topic appears all the more remarkable.

Over the past decades, countless memoirs, articles, and even blockbuster movies have recollected what has emphatically been described as "the greatest displacement of works of art in history," the looting of Jewish and public collections across fascist-occupied Europe and the subsequent efforts to restore them to their rightful owners. ${ }^{6}$ These popular recollections often remain marred by a noticeable lack of historical accuracy and depth. Since the end of the Cold War, however, a growing number of historians, art historians, legal scholars, and provenance researchers have devoted their energy to investigating the nuances and complexities of the phenomenon across time and space. A wide-ranging scholarship relating to Jewish private and communal property in general - especially, the contentious cases of bank accounts, insurance, and gold - has provided valuable insights from both historical and legal perspectives, particularly on dispossession practices, ${ }^{7}$ the disputed process of "Aryanization," the postwar work of Jewish organizations," and the restitution campaigns of the $1990 \mathrm{~s} .{ }^{10}$ When it comes to the subject of cultural property, in particular, pioneering works published in the 1990s - Lynn Nicholas and Jonathan Petropoulos in primis ${ }^{11}$ - and the flurry of activities surrounding the 1998 signing of the Washington Conference Principles on Nazi-Confiscated Art paved the way for what is now an impressive body of in-depth contributions focusing on specific Western and Central European collections, places, and actors. ${ }^{12}$

\footnotetext{
${ }^{5}$ See the classic Anderson 1991; see also Jenny Graham, “The Ghent Altarpiece after World War II: Restitution, Redemption, Restoration" in this issue.

${ }^{6}$ Nicholas 1999, 449.

${ }^{7}$ See Dean 2008.

${ }^{8}$ See Goschler and Lillteicher 2002.

${ }^{9}$ See, e.g., Takei 2002; Lillteicher 2007, 357-98; Gallas 2015.

${ }^{10}$ See Marrus 2009.

${ }^{11}$ See Nicholas 1994; Petropoulos 1996. Other pioneering works include Feliciano 1997.

12 Two compelling examples remain Lillie 2003; Bambi and Drecoll 2015. It should be noted that the majority of this literature is still in German, not only as a result of strong public pressure and the accessibility of the sources but also of the financial support to undertake these studies. Washington Principles on Nazi-Confiscated Art, 3 December
} 
Besides constituting valuable case studies, the examination of the fate of renowned artworks or individual art dealers has shed significant light on the mechanisms of dispossession and restitution as well as on the impact of Cold War politics and the persistence of anti-Semitic attitudes in the post-1945 period. ${ }^{13}$ The analysis of immediate postwar restitution activities - especially of the Monuments, Fine Arts, and Archives (MFA\&A) division ${ }^{14}$ or of the Central Collecting Points established by the Western Allies in occupied Germany ${ }^{15}$ was pivotal, for instance, in highlighting the continuities in both personnel and policies across the 1945 divide and the role of pre- and postwar professional networks. ${ }^{16}$ Furthermore, the partial opening of the Russian archives has facilitated the appearance of the first comparative or transnational studies focusing not only on artworks but also on books and archives..$^{17}$ Even when it comes to some scholarly works, however, the field still appears partly compartmentalized along institutional, disciplinary, or national boundaries or circumscribed to descriptive analyses of individual art collections or dealers. At the same time, a substantial literature is now developing on the restitution of colonial artifacts, prompted by the publishing of the 2018 Sarr-Savoy report and the Black Lives Matter movements, which bring to the fore the broader issue of the points of contact and divergence between post-fascist and postcolonial restitution. ${ }^{18}$

Bringing together new research in the field, this special issue explores the untapped potential of historical and art historical research into the restitution of fascist-looted art (whether successful, failed, or in fieri) by pushing for an interdisciplinary historicization of its subject. This was pursued from different perspectives and at varying degrees, as the articles that form this issue illustrate. They all use sources and methods of provenance research to ask different questions and to shed light on new historical themes in order to integrate provenance research into bigger historical and methodological queries. All of them represent a first step to go beyond the history of the trajectory of a certain work of art or a confined analysis of the art world toward the bigger questions of society, identity, politics, and gender that material culture can help to answer. Art is a colorful topic, charged with a mystic, emotional, and glamorous component, and it makes for great storytelling yet it seems important to integrate these stories into broader historical research. The authors of this collection hail from various disciplines and thus approach their subject from a number of different angles.

The collection opens with Jenny Graham's thought-provoking longue durée analysis of the vivid case of the Ghent altarpiece as a lens to explore competing national narratives and identities, demonstrating that art objects have themselves a strong cultural and, in the case of looted art, political history. In her article "The Ghent Altarpiece after World War II: Restitution, Redemption, Restoration," Graham provides a compelling reading of surprising sources, the published debates on professional methods of conservation. She shows how the historical narrative of looting and restitution of a piece of art is shaped into a communal memory and exceptional collective meaning and, thus, appropriated and re-appropriated from various political and professional quarters. The much-mythologized Ghent altarpiece was charged with meaning that placed it almost outside history as a universal measure of

1998, https://www.state.gov/washington-conference-principles-on-nazi-confiscated-art/ (accessed 2 November 2019).

${ }^{13}$ For an overview of recent debates, see Gaudenzi 2020, 191-208.

${ }^{14}$ See, e.g., Kurtz 2006.

15 See Bernsau 2013; Lauterbach 2018.

${ }^{16}$ See Petropoulos 2017.

${ }^{17}$ See Grimsted et al. 2013. This is also true of German and Jewish studies more generally. See, e.g., Gallas 2019; on the "repatriation" of Jewish community archives to Israel, see Lustig 2021.

${ }^{18}$ See Sarr and Savoy 2018. 
human achievement. Its varied history of "rescue, restitution and rightful custodianship" can also be seen as a carefully contrived conflation of the spirit and the state, turning the religious into a secular relic in its own right. In absence of a unifying Belgian language or literature, art could be a solid and reliable foundation for a fantasy of historic national unity and continuing national triumph. Graham's article entangles the numerous historical themes and interests that color a highly instrumental care of artworks and reflect the bigger themes of postwar Europe: nationalism and internationalism, social stability and postwar healing, the influence of modern science, and the professionalization of museum and conservation work.

The art at the center of Emily Löffler's contribution could not be more different. In her article "'Living Room Art' and the Material Culture of Provenance: Retracing Bourgeois Everyday Life and Art Collecting Practices through Restitution Files," Löffler examines the social relevance of material culture by enquiring into the role of "living room art" - that is, artworks generally overlooked due to their dubious artistic quality, which constituted important markers of their owners' social and cultural status. Löffler enquires into "living room art" belonging to Jewish middle-class families that was confiscated and given to the Landesmuseum in Mainz in 1943, immediately after their owners had been deported - thereby revealing a distressing parallel between the destruction of material culture and the destruction of lives. Living room art is a term she introduces for an artwork that is neither artistically accomplished nor innovative but that is similarly a symbol for something beyond its material quality.

Consulting inventory lists and household descriptions, Löffler's approach to material culture takes us immediately to a particular person or place, to a way of thinking and of acting that may be difficult to recover if we work only from texts or look top-down at broader historical currents. In this case, the sources of provenance research are a tool to investigate the artworks' social function. They furthermore provide new and noteworthy insights not only into German-Jewish collecting practices, ideas of self-representation and bourgeois taste but also into the ways in which persecution impacted their sense of (material) belonging in the 1940s. Her highly original approach compellingly reframes object-based provenance research and combines it with a material culture studies approach in order to answer these often-overlooked research questions and point toward new and fruitful avenues of inquiry.

Identity is also the focus in MaryKate Cleary's article "Marie-Louise von Motesiczky: Renegotiating the Self-portrait as a Woman Émigré Artist in the Nazi Era." Cleary's analysis of the shifting of individual and collective identities and self-perceptions as exemplified by the works of painter and refugee Marie-Louise von Motesiczky demonstrates how fruitful art is as a source to study the emotions of material culture and the aestheticization of gender and history. Cleary consults a fascinating corpus of visual sources that document the painter's life through a special medium: self-portraits. The artworks provide a compelling case for changing perceptions of the self as an artist, a refugee, and a woman. Motesiczky, a member of the Austrian Jewish upper class who were forced to flee their country in 1938, was herself a claimant of looted art, as evidenced by Ines Schlenker's contribution to this issue. A much greater impact than the loss of possessions and material culture, though, was the loss of her sense of homeland and belonging, as she was forced to negotiate a new existence as refugee. By examining the artist's life-long process of introspection, Cleary well illustrates how Motesiczky adapted to new social circumstances, reclaimed her agency as an artist as well as a woman, and experienced consequent shifts in identity in her new homeland, England. Intertwining the study of material culture with art-historical analysis, she carefully peels back the layers of personal meaning and societal context in Motesiczky's paintings to lay bare the impact the historical had on the private. In doing so, the article shines a revealing light on two still under-researched topics: the female experience of exile and that of women 
artists. Fascinatingly, Cleary suggests that "exile as a life-long status should not only be seen as negative but also as an inspirational force with a direct influence on an artist's work, enacting a liberatory potential that must also form part of our understanding of the agency reclaimed by Jewish émigrés after the Holocaust." 19

Gender is also the fil rouge of Elizabeth Campbell's paper entitled "Monuments Women and Men: Rethinking Popular Narratives via British Major Anne Olivier Popham." Campbell covers another rather uncharted aspect of this history by enquiring into the everyday restitution practices of British forces in occupied Germany through an in-depth study of the gendered experience of "Monuments Woman" Major Anne O. Popham (1916-2018). Campbell thereby aims to rectify popularized cinematic and literary depictions of restitution practices, which are usually US-centric, largely masculine, and triumphant, and largely elide the role played by women and other Allied forces. While the MFA\&A division was a US-led operation, the art restitution effort relied on the leadership, talent, and dedication of some 350 officers - male and female - from 14 Western Allied nations. Drawing on Popham's diaries, a personal interview with her, and material from British and US archives, the case study yields important insight into the working conditions of the MFA\&A personnel, the gender relations among the officers and how they were perceived by their contemporaries, and the insufficient transnational cooperation in professional day-to-day endeavors. Equally importantly, Popham's experience also documents the silence that surrounded the restitution of Jewish cultural property, which is all the more striking given the fact that a few repositories were located in the British zone of Germany (and Austria).

Jennifer Gramer tackles a completely different corpus of confiscated art, the paintings of German combat artists - the so-called Kriegsmaler - whose paintings were seized by the US army at the end of World War II. In her empirical contribution "Monuments of German Baseness: Confiscated Nazi War Art and American Occupation in the United States and Postwar Germany," Gramer contextualizes the fierce contemporary debates on the "incendiary" quality of art. After 1945, war art was deemed morally incendiary and considered a dangerous instrument of Nazi revival. After all, it was the National Socialist regime that commissioned these painters to document, narrate, and glorify German victories and anticipated Allied defeats. As an instrument of propaganda, these artworks were not protected by laws prohibiting art looting. Arguing that combat art was not necessarily propaganda or Nazi art, Gramer investigates the ambivalent attitudes held by different representatives of the US army that led to the eventual return of the paintings to West Germany.

What is fascinating in this context, again, is the role that is ascribed to art, which differentiates it from other objects of material culture. In its role as propaganda, art was invested with a dangerous charisma able to trigger or glorify Nazi politics. At the same time, US military personnel attributed a certain universal quality to the paintings - that of a shared human experience, of what it means to be at war. Despite their artistic merit, these artworks were thereby classified as historical documents of a specific moment in time, pointing toward a transnational culture of military art across political systems. By juxtaposing these different conceptions of war art, Gramer demonstrates that the confiscation and repossession of artworks was ridden with complexity, individual circumstances, and postwar political sensitivities.

How restitution policies can brilliantly elucidate political historical developments is also at the heart of Ulrike Schmiegelt-Rietig's examination of the Pechory Monastery treasure, whose restitution was strongly opposed by competing political interests for most of the Cold

\footnotetext{
${ }^{19}$ See MaryKate Cleary, "Marie-Louise von Motesiczky: Re-negotiating the Self-portrait as a Woman Émigré Artist in the Nazi Era" in this issue.
} 
War. In her article "A Hostage of the Cold War? The Return of the Monastery Treasure of Pechory," Schmiegelt-Rietig presents a fascinating case study of one of the first acts of West German restitution to the Soviet Union at the height of the Cold War. An exemplary case of the politically very significant and sensitive issue of German (and Western) restitution to the Soviet Union, her article draws on revealing archival sources - the Georg Stein dossier, in particular - which are accessed and discussed for the first time. Schmiegelt-Rietig explores the political role of art beyond cultural diplomacy. Her article beautifully demonstrates how sources and methods of provenance research can help to reflect and explore shifting international relations and policies more generally and how the centrality of the Cold War influenced and hampered the ante-litteram practice of "just and fair" solutions.

Finally, there are indeed still many fascinating stories to tell about the trajectory of single artworks, the paramount importance of informal networks, and the ambiguous continuities that characterized the wartime and postwar art market and its personnel. This is evidenced by Ines Schlenker's article "Saving St Christopher: The History of a Looted Painting", on the fate of the sixteenth-century painting St Christopher Meeting the Devil. Prized away in 1938 from its legitimate owners, the Viennese family of Marie-Louise von Motesiczky, the painting is nowadays on exhibit at the Fitzwilliam Museum in Cambridge, after being returned surprisingly swiftly to the Motesiczkys in 1950.

The interdisciplinary conversation between different empirically rich instances of material culture that underpins this issue can also contribute to opening up inspiring new avenues of research. The examination of "living room art" represents an exciting and innovative field of inquiry for the history of fascist and post-fascist Europe, for sure. Incorporating the suggestions of gender studies can also significantly enhance the scholarly impact of researches into restitution praxes - for instance by highlighting the social implications of gender and sexual orientation in a narrative still too often dominated by male heterosexual networks - despite the actual role played by "Monuments Women" like Rose Valland, Ardelia Ripley Hall, Motoko Fujishiro, Edith Standen, or, indeed, Anne O. Popham. ${ }^{20}$ The analysis of material culture in its identity-building and social functions can shed light on the still under-researched fruition and reception side of cultural consumption. This proves particularly true when examining cultural items more broadly speaking - from communal or private libraries to local archives, furniture, china, or everyday kitchen sets. Budding studies in everyday material culture, in particular, promise to open insightful new ways to examine the self-image of different social groups - particularly the middle classes - through their Objektkultur and thereby provide valued contributions to the realm of Alltagsgeschichte and social history more broadly. On the other side of the spectrum, institutional histories of historical or truth commissions are now giving way to works that reflect on the relationship between Holocaust memory and history and provide compelling material for a more comprehensive understanding of Europe's processing of its genocidal past. ${ }^{21}$

Further research opportunities lay ahead. Recent incursions into the history of emotions have successfully led the way in highlighting the symbolic meaning of cultural objects and their impact on identity and family history. ${ }^{22}$ Research on memory and the spatial turn have also set the stage for the future historicization of looted art as lieu de memoire, along the lines of Aleida Assmann's concept of the inalienable nature of places for the construction of cultural memory. ${ }^{23}$ Exploring the everyday history of plundering and restitution at the local, transnational, and global level, finally, aims at contextualizing the history of the Holocaust

\footnotetext{
${ }^{20}$ Captain Rose Valland is the best known in English. See Bouchoux 2013.

${ }^{21}$ For an overview, see Karn 2015.

${ }^{22}$ See Savoy 2015.

${ }^{23}$ Cf. Nora 1984-92; Assmann 1999, $298 \mathrm{ff}$.
} 
within the longue durée of looting (and restitution) while spotlighting its central relevance for present-day debates and global history more broadly. This appears particularly relevant in the case of postcolonial restitution, the growing significance of which can also provide a fruitful terrain to enquire into the interplay between the international, national, and local scenarios, the role played by transnational agencies and regulations as well as the relevance of cultural property for nation (re)building in the postcolonial world.

It is precisely by fully grasping the many layers of restitution that the historical phenomena of looting and restitution can spotlight unchartered aspects of Europe's social and political history since the end of World War II. After all, in history, provenance nuances are essential for understanding the complexities of the past as well as for finding solutions for the future.

Acknowledgments. Thanks to Sotheby's London and in particular Richard Aronowitz, Victoria Steinwachs, and Julia Rickmeyer.

Author contributions. Bianca Gaudenzi authored pages 333-336 and 339-341; Lisa Niemeyer pages 337-338.

\section{Bibliography}

Anderson, Benedict. 1991. Imagined Communities: Reflections on the Origin and Spread of Nationalism. Rev. ed. London: Verso.

Assmann, Aleida. 1999. Erinnerungsräume. Formen und Wandlungen des kulturellen Gedächtnisses. Munich: C. H. Beck. Bambi, Andrea, and Axel Drecoll, eds. 2015. Alfred Flechtheim. Raubkunst und Restitution. Berlin: De Gruyter.

Bernsau, Tanja. 2013. Die Besatzer als Kuratoren? Der Central Collecting Point Wiesbaden als Drehscheibe für einen Wiederaufbau der Museumslandschaft nach 1945. Berlin: Lit.

Bouchoux, Corinne. 2013. Rose Valland: Resistance at the Museum. Dallas, TX: Laurel Publishing.

Dean, Martin. 2008. Robbing the Jews: The Confiscation of Jewish Property in the Holocaust, 1933-1945. Cambridge, UK: Cambridge University Press.

Feliciano, Hector. 1997. The Lost Museum: The Nazi Conspiracy to Steal the World's Greatest Works of Art. New York: Basic Books.

Gallas, Elisabeth. 2015. "Locating the Jewish Future: The Restoration of Looted Cultural Property in Early Postwar Europe." Naharaim 9, nos. 1-2: 25-47

Gallas, Elisabeth. 2019. A Mortuary of Books: The Rescue of Jewish Culture after the Holocaust. New York: New York University Press.

Gaudenzi, Bianca. 2020. “Crimes against Culture: From Plunder to Postwar Restitution Politics.” In The WileyBlackwell Companion to the Holocaust, edited by S. Gigliotti and H. Earl, 191-208. London: John Wiley \& Sons.

Gaudenzi, Bianca. 2021. "The 'Return of Beauty'? The Politics of Restitution of Nazi-looted Art in Italy, the Federal Republic of Germany and Austria, 1945-1998." European Review of History / Revue européenne d'histoire 28, no. 2: 323-46.

Gaudenzi, Bianca, and Astrid Swenson. 2017. "Looted Art and Restitution in the Twentieth Century: Towards a Global Perspective.” Journal of Contemporary History 52, no. 3: 491-518.

Goschler, Constantin, and Jürgen Lillteicher. eds. 2002. "Arisierung" und Restitution: die Rückerstattung jüdischen Eigentums in Deutschland und Österreich nach 1945 und 1989. Göttingen, Germany: Wallstein.

Grimsted Patricia K. et al., eds. 2013. Returned from Russia: Nazi Archival Plunder in Western Europe and Recent Restitution Issues: afterword. Builth Wells, UK: Institute of Art and Law.

Karn, Alexander. 2015. Amending the Past: Europe's Holocaust Commissions and the Right to History. Madison: University of Wisconsin Press.

Kurtz, Michael J. 2006. America and the Return of Nazi Contraband: The Recovery of Europe's Cultural Treasures. Cambridge, UK: Cambridge University Press.

Lauterbach, Iris. 2018. The Central Collecting Point in Munich: A New Beginning for the Restitution and Protection of Art. Los Angeles: Getty Research Institute.

Lillie, Sophie. 2003. Was einmal war. Handbuch der enteigneten Kunstsammlungen Wiens. Vienna: Czernin Verlag.

Lillteicher, Jürgen. 2007. Raub, Recht und Restitution. Die Rückerstattung jüdischen Eigentums in der frühen Bundesrepublik. Göttingen, Germany: Wallstein.

Ludi, Regula. 2018. "Second-Wave Holocaust Restitution, Post-Communist Privatization, and the Global Triumph of Neoliberalism in the 1990s." Yod 21: n.p.

Lustig, Jason. 2021. A Time to Gather: Archives and the Control of Jewish Culture. Oxford: Oxford University Press. 
Marrus, Michael. 2009. Some Measure of Justice: The Holocaust Era Restitution Campaign of the 1990s. Madison: University of Wisconsin Press.

Nicholas, Lynn H. 1994. The Rape of Europa: The Fate of Europe's Treasures in the Third Reich and the Second World War. New York: Vintage Books.

Nicholas, Lynn H. 1999. Proceedings of the Washington Conference on Holocaust-Era Assets: November 30 - December 3, 1998, Department of State Publications no. 10603. Washington, DC: US Government Printing Office.

Nora, Pierre, ed. 1984-92. Les Lieux de mémoire. Vols. 1-7. Paris: Gallimard.

Petropoulos, Jonathan. 1996. Art as Politics in the Third Reich. Chapel Hill: University of North Carolina Press.

Petropoulos, Jonathan. 2017. "Art Dealer Networks in the Third Reich and in the Post-War Period." Journal of Contemporary History 52, no. 3: 546-65.

Sarr, Felwine, and Bénédicte Savoy. 2018. The Restitution of African Cultural Heritage. Toward a New Relational Ethics. http://restitutionreport2018.com/sarr_savoy_en.pdf (accessed 20 January 2022).

Savoy, Bénédicte. 2015. "Plunder, Restitution, Emotion and the Weight of Archives: A Historical Approach." In Echoes of Exile: Moscow Archives and the Arts in Paris 1933-1945, edited by I. Rotermund-Reynard, 27-44. Berlin: De Gruyter.

Takei, Ayaka. 2002. “The 'Gemeinde Problem': The Jewish Restitution Successor Organization and the Postwar Jewish Communities in Germany, 1947-1954.” Holocaust and Genocide Studies 16, no. 2: 266-88.

Cite this article: Gaudenzi, Bianca, and Lisa Niemeyer. 2021. "Between material culture and 'living room art': Historicizing the restitution of fascist-looted art." International Journal of Cultural Property 28, no. 3: 333-341. https:// doi.org/10.1017/S0940739122000029 